\title{
Altered Arrangement of Proteins in the Spore Coat of a Germination Mutant of Bacillus subtilis
}

\author{
By H. F. JENKINSON† \\ Microbiology Unit, Department of Biochemistry, University of Oxford, Oxford OX1 3QU, U.K.
}

(Received 6 October 1982; revised 16 November 1982)

\begin{abstract}
Spores produced by a mutant of Bacillus subtilis were slow to develop their resistance properties during sporulation, and were slower to germinate than were wild-type spores. The coat protein composition of the mutant spores, as analysed by SDS-PAGE, was similar to that of the wildtype spores. However, one of the proteins (mol. wt 12000) which is normally present in the outermost layers of mature wild-type spores and which is surface-exposed, was assembled abnormally into the coat of the mutant spores and not surface-exposed. The mutation responsible for this phenotype (spo-520) has been mapped between phe A and leuB on the B. subtilis chromosome, and was $47 \%$ cotransformable with leuB 16 . This mutation, and three others closely linked to it, define a new sporulation locus, spoVIB, which is involved in spore coat assembly. The phenotype of the mutant(s) supports the contention that spore germination and resistance properties may be determined by the assembly of the coat.
\end{abstract}

\section{INTRODUCTION}

The spore coat proteins in Bacillus subtilis are a class of sporulation-specific gene products that are assembled on the developing spore during stages V to VI of sporulation (Jenkinson $e t$ al., 1981). The formation of the coat occurs in parallel with the development by the spores of their germination properties (Dion \& Mandelstam, 1980) and their resistance properties (Jenkinson et al., 1980) and there is evidence that the coat plays a role in determining these properties (Aronson \& Fitz-James, 1976; Stelma et al., 1978, 1980; Moir, 1981; Jenkinson, 1981).

Recently, two mutations in separate genetic loci have been shown to affect coat formation in B. subtilis (Moir, 1981; Jenkinson, 1981). The expression of one of these loci (spoVIA) is known to be required for the synthesis at stage $\mathrm{V}$ of one of the major outer-coat proteins (Jenkinson, 1981); spores lacking this protein are sensitive to lysozyme (Jenkinson et al., 1981; Jenkinson, 1981).

This paper describes the isolation and phenotypic properties of four new sporulation mutants. The mutants are slower to sporulate than normal, and form spores that are slow to germinate and in which the coat proteins are misarranged. The mutations map close to leuB16 $(41-50 \%$ cotransformation) and together they define a new sporulation locus, spoVIB, involved in coat assembly.

\section{METHODS}

Bacteria. Bacillus subtilis 168 trpC2 which sporulates normally was used and is referred to as the wild-type strain. Stocks were kept at $4^{\circ} \mathrm{C}$ as dilute spore suspensions in distilled water. Other strains used are listed in Table 1 . Induction of sporulation. Cells were grown in hydrolysed casein medium to an $A_{600}$ of 0.80 ( $\sim 0.25 \mathrm{mg}$ dry wt $\mathrm{ml}^{-1}$ ) and induced to sporulate by resuspension at the same density in glutamate/inorganic salts medium containing tryptophan $\left(20 \mu \mathrm{g} \mathrm{ml}^{-1}\right)$ or other appropriate amino acid supplement $\left(200 \mu \mathrm{g} \mathrm{ml}^{-1}\right)$ (Sterlini \&

† Present address: Department of Oral Biology, University of Otago, Box 647, Dunedin, New Zealand.

Abbreviation: PGYE agar, potato extract/glucose/yeast extract agar. 
Table 1. Strains of B. subtilis used

Laboratory stock strains

\begin{tabular}{ll}
$\begin{array}{c}\text { Strain } \\
\text { designation }\end{array}$ & \multicolumn{1}{c}{ Genotype } \\
168 & trpC2 \\
MB8 & hisA1 \\
MB21 & metC3 leuA8 tal-1 \\
MB26 & pheA12 leuA8 rfm tal-1 \\
MB68 & pheA12 lys 1 rfm tal-1 \\
MB79 & pheA12 metC3 tal-1 \\
MY2016 & hisH2 lys-1 rfm Sul \\
BD112 & cysA14 \\
CU267 & trpC2 ilvB2 leuBl6 \\
JH326 & leu-2 citF78 \\
4823 & leu-2 citF2 \\
4673 & gerE36 \\
513 & trpC2 spoVIA513 \\
513.1 & leuA8 spoVIA513
\end{tabular}

Source

Reference

This laboratory

This laboratory

This laboratory

This laboratory

This laboratory

This laboratory

This laboratory

D. Dubnau

S. Zahler

J. Hoch

L. Rutberg

A. Moir

This laboratory

This laboratory

Yudkin \& Turley (1980)

Ohné et al. (1973)

Ohné et al. (1973)

Moir (1981)

Jenkinson (1981)

Jenkinson (1981)

Constructed strains

Strain

designation

520

520.1

520.3

524

541

547

552

541.1

547.1

552.1

\section{Genotype}

$\operatorname{trpC2}$ spo-520

metC3 spo-520

$\operatorname{trpC2}$ spo-520

spo-513 spo-520

trpC2 spo-541

trpC2 spo-547

$\operatorname{trpC2}$ spo-552

leuB16 trpC2 spo-541

leuB16 trpC2 spo-547

leuB 16 trpC2 spo-552

\section{Construction}

NTG mutagenesis of strain 168 (Jenkinson, 1981)

520 (DNA) $\rightarrow$ MB79; Phe $^{+}$recombinants scored for congression of spo-520

520 (DNA) $\rightarrow$ CU267; $\mathrm{Ilv}^{+} \mathrm{Leu}^{+}$recombinants

scored for cotransformation of spo-520

520 (DNA) $\rightarrow 513.1$; Leu $^{+}$recombinants scored for cotransformation of $s p o-520$

Localized NTG-mutagenesis (this paper)

541 (DNA) $\rightarrow$ CU267; $\mathrm{Ilv}^{+}$recombinants scored for cotransformation of spo-54I

547 (DNA) $\rightarrow$ CU267; $\mathrm{Ilv}^{+}$recombinants scored for cotransformation of spo-547

552 (DNA) $\rightarrow$ CU267; $\mathrm{Ilv}^{+}$recombinants scored for cotransformation of spo-552

Mandelstam, 1969). After incubation with shaking at $37^{\circ} \mathrm{C}$ for $8 \mathrm{~h}, 80-90 \%$ of the cells contained phase-bright, fully refractile spores as visualized by phase-contrast microscopy. The terms 'phase-grey' and 'phase-dark' refer respectively to spores that are not fully refractile, and to spores that have no refractility, e.g. stage III pre-spores. Times of resuspension (h) are denoted by $t_{1}, t_{2}$, etc.

Measurement of sporulation marker events. Extracellular serine protease was measured by the method of Dancer \& Mandelstam (1975); alkaline phosphatase was determined as described by Glenn \& Mandelstam (1971), and extracellular sporulation endonuclease estimated by the method of Akrigg (1978). Glucose dehydrogenase was measured by the method of Sadoff (1966), and 2,6-dipicolinic acid was determined as described by Janssen et al. (1958).

Measurement of resistance of spores to toluene, heat and lysozyme. Resistance to toluene and heat was determined as described by Jenkinson et al. (1980). The numbers of spores surviving incubation with lysozyme (EC 3.2.1 17; $250 \mu \mathrm{g} \mathrm{ml} l^{-1}, 37^{\circ} \mathrm{C}, 30 \mathrm{~min}$ ) were determined by plating suitable dilutions on nutrient agar (Oxoid).

Preparation of spores. Spores and sporangia were harvested from cultures by centrifugation $(8000 \mathrm{~g}, 10 \mathrm{~min}$, $4{ }^{\circ} \mathrm{C}$ ), washed with $\mathrm{KCl}(1 \mathrm{M})$ and then with $\mathrm{NaCl}(0.5 \mathrm{M})$. The pellets were suspended to a density of about $20 \mathrm{mg}$ dry wt $\mathrm{ml}^{-1}$ in TEP buffer $(50 \mathrm{mM}$-Tris/ $\mathrm{HCl}, \mathrm{pH} 7.2$ containing $5 \mathrm{mM}$-EDTA and $2 \mathrm{mM}$-phenylmethylsulphonyl fluoride) and passed twice through an ice-cold French pressure cell at $83 \mathrm{MPa}$. This released $>90 \%$ of the spores from sporangia. The French-press treatment was omitted for the preparation of spores from cultures at $t_{20}$ because these were kept at $4{ }^{\circ} \mathrm{C}$ for $48 \mathrm{~h}$ to allow complete cell lysis to occur, before the spores were harvested and washed as described above. The suspension was then diluted to $30 \mathrm{ml}$ in TEP buffer containing $0.001 \%$ Tween 80 , centrifuged $\left(2000 \mathrm{~g}, 5 \mathrm{~min}, 4^{\circ} \mathrm{C}\right)$, and the spores were washed twice more with $30 \mathrm{ml} \mathrm{TEP}$. In some cases the spore 
coat proteins were extracted as described below without further cleaning of the spores. For germination experiments the spores were further purified by centrifugation through $50 \%(\mathrm{w} / \mathrm{v}$ ) Urografin (Jenkinson, 1981).

Spore coat proteins. For extraction of the coat proteins, spores were suspended at a density of about $10 \mathrm{mg}$ dry wt $\mathrm{ml}^{-1}$ in TEP buffer $(10 \mathrm{ml})$ and broken with glass beads in a Braun Model MSK cell homogenizer (4 min, full speed). The insoluble fraction after breakage was treated with lysozyme $\left(50 \mu \mathrm{g} \mathrm{ml}^{-1}, 40^{\circ} \mathrm{C}, 30 \mathrm{~min}\right)$ and then extensively washed as previously described (Jenkinson et al., 1981). The residue was termed the 'spore coat fraction' and the coat proteins were solubilized from this with DS buffer $[0.5 \mathrm{ml}$ cyclohexylaminoethanesulphonic acid/ $\mathrm{NaOH}$ buffer $(5 \mathrm{mM}, \mathrm{pH} 9.8)$ containing SDS $(1.5 \%, \mathrm{w} / \mathrm{v})$ and dithioerythritol $(50 \mathrm{~mm})]$, and prepared for electrophoresis as described by Jenkinson et al. (1981).

Solubilization of coat proteins with DTT/urea followed by $\mathrm{NaOH}$. Cleaned spores from $t_{20}$ cultures were suspended at a density of $1 \mathrm{mg} \mathrm{ml}^{-1}$ in $50 \mathrm{~mm}$-DTT/8 M-urea pH $3(0.5 \mathrm{ml})$ and incubated for $1 \mathrm{~h}$ at $37^{\circ} \mathrm{C}$. The suspension was centrifuged, the spores were washed twice with water $(0.5 \mathrm{ml})$ and then treated with $0.1 \mathrm{M}-\mathrm{NaOH}(0.5 \mathrm{ml})$ at $4{ }^{\circ} \mathrm{C}$ for $15 \mathrm{~min}$ (Gould et al., 1970). The spores were then pelleted by centrifugation, washed once with water and resuspended to an $A_{550}$ of 0.50 in $\mathrm{NaH}_{2} \mathrm{PO}_{4} / \mathrm{NaOH}$ buffer (100 mM, pH 7). All solutions contained Tween 80 $(0.0002 \%)$ to minimize clumping of spores.

Germination properties. Spores from cultures at $t_{20}$ were harvested and washed as described above. They were then suspended at a density of $5 \times 10^{7}$ spores $\mathrm{ml}^{-1}$ at $25^{\circ} \mathrm{C}$ in the germinant being tested, and germination was followed either by measuring loss of absorbance at $550 \mathrm{~nm}$ or by removing samples $(0 \cdot 1 \mathrm{ml})$ at intervals and measuring the numbers of spores surviving toluene treatment.

$S D S-P A G E$. Proteins were fractionated by electrophoresis in $15 \%(\mathrm{w} / \mathrm{v})$ acrylamide slab gels as described by Jenkinson et al. (1981) using the system of Laemmli \& Favre (1973).

Surface-protein iodination. Cleaned spores $\left(5-10 \mathrm{mg}\right.$ dry wt) were surface-labelled with ${ }^{125}$ I (New England Nuclear) using lactoperoxidase (EC 1.11.1.7; Sigma) (Jenkinson et al., 1981). The spore coat proteins were then fractionated by SDS-PAGE and the ${ }^{125} \mathrm{I}$ associated with each band was determined by counting $1 \mathrm{~mm}$ slices in an LKB Wallac 1270 Rackgamma counter.

Mapping by PBS1 transduction. Transducing lysates were prepared from the donor strain as described by Karamata \& Gross (1970). For transduction, the recipient strain was grown at $37^{\circ} \mathrm{C}$ in Brain Heart Infusion Broth (Oxoid) containing $0.5 \%$ (w/v) Yeast Extract (Oxoid) until the cells were motile, and then $1 \mathrm{ml}$ was incubated with $0.1 \mathrm{ml}$ phage lysate with gentle shaking at $37^{\circ} \mathrm{C}$ for $30 \mathrm{~min}$. The cells were harvested by centrifugation, washed twice in minimal salts medium $(10 \mathrm{ml}$ ) (Anagnostopoulos \& Spizizen, 1961) containing $0.5 \%(\mathrm{w} / \mathrm{v}) \mathrm{glucose}$, suspended in $1 \mathrm{ml}$ fresh salts medium and $0.1 \mathrm{ml}$ portions were plated on lactate/glutamate minimal agar (Piggot, 1973) with appropriate supplements. After incubation of the plates for $48 \mathrm{~h}$ at $37^{\circ} \mathrm{C}$, colonies were picked for scoring as described below

Preparation of transforming DNA. DNA for transformation was prepared by one of two methods. For the construction of strains, DNA was prepared by the method of Ward \& Zahler (1973). For mapping of linked genes, DNA was prepared by the method of Marmur (1961) and its concentration was estimated from the $A_{260}$ of a solution in saline-sodium citrate $(0.15 \mathrm{M}-\mathrm{NaCl}$ in $0.015 \mathrm{M}$-sodium citrate, $\mathrm{pH} \mathrm{7 \cdot 0)}$.

Preparation of competent cells. Cells were made competent as follows. Pre-transformation medium (5 ml) was inoculated with a single colony isolate of the recipient strain previously grown for $18 \mathrm{~h}$ at $37^{\circ} \mathrm{C}$ on nutrient agar [or on Tryptone Blood Agar base (Difco) containing 0.5\% glucose for strains harbouring the cit $F$ mutation]. The composition of pre-transformation medium was essentially the same as that described by Anagnostopoulos \& Spizizen (1961) except that the casein hydrolysate (Oxoid) concentration was increased to $0 \cdot 2 \%(\mathrm{w} / \mathrm{v})$, and $\mathrm{MnSO}_{4} \cdot 4 \mathrm{H}_{2} \mathrm{O}(0 \cdot 5 \mu \mathrm{M})$ and $\mathrm{CaCl}_{2}(50 \mu \mathrm{M})$ were included (M. Young, personal communication). The cells were grown in pre-transformation medium at $37^{\circ} \mathrm{C}$, with shaking, to stationary phase $\left(A_{600} \sim 3 \cdot 0\right)$ and then diluted 10 fold into warm transformation medium (Young \& Spizizen, 1961).

Transformation. Transforming DNA was added to competent cells $(1 \mathrm{ml})$ at a concentration of either $0.05 \mu \mathrm{g} \mathrm{ml}^{-1}$ (for mapping) or at a saturating concentration $\left(\sim 1 \mu \mathrm{g} \mathrm{ml}^{-1}\right)$ for congression of unlinked genes. The cultures were shaken for $90 \mathrm{~min}$ at $37^{\circ} \mathrm{C}$, diluted 10 - and 100 -fold in transformation medium, and $0 \cdot 1 \mathrm{ml}$ samples were plated on to lactate/glutamate minimal agar with appropriate supplements.

Preparation of heavily mutagenized DNA for localized mutagenesis. An overnight culture of strain $168 \operatorname{trpC2}$ in Penassay broth (Antibiotic medium no. 3, Difco) was diluted in fresh, warm Penassay broth to a cell density of about $1 \times 10^{8} \mathrm{c}$.f.u. $\mathrm{ml}^{-1}$ and grown with shaking at $37^{\circ} \mathrm{C}$ to a density of about $4 \times 10^{8} \mathrm{c.f}$.u. $\mathrm{ml}^{-1}$. The cells were harvested by centrifugation, suspended in $10 \mathrm{ml}$ resuspension medium (see above) and treated with NTG ( $N$ methyl- $N^{\prime}$-nitro- $N$-nitrosoguanidine, final concentration $100 \mu \mathrm{g} \mathrm{ml}^{-1}$ ) for $30 \mathrm{~min}$ at $37^{\circ} \mathrm{C}$ with gentle shaking. The cells were then harvested by centrifugation, washed twice with fresh Penassay broth ( $40 \mathrm{ml}$ each time) and suspended in $200 \mathrm{ml}$ warm, aerated Penassay broth and incubated with shaking for a further $1 \mathrm{~h}$ at $37^{\circ} \mathrm{C}$. The cells were then pelleted by centrifugation and the DNA was extracted by the method of Marmur (1961).

Scoring of recombinants. Single colony isolates of transductants and transformants were picked on to lactate/ glutamate minimal agar containing appropriate supplements and on to potato extract/glucose/yeast extract 
(PGYE) agar and scored for germination deficiency by the tetrazolium overlayer method (Lafferty \& Moir, 1977). In some cases, colonies of recombinants carrying the sporulation mutation could be easily distinguished on PGYE agar by their translucence after chloroform-treatment and the tetrazolium overlay was not necessary. However, they could only occasionally be distinguished from colonies of the recipient strains on the basis of pigment production or opacity on lactate/glutamate minimal agar.

Chemicals. Acrylamide, $N, N^{\prime}$-methylenebisacrylamide and SDS were from BDH. All other chemicals, unless otherwise stated, were from Sigma.

\section{RESULTS}

Times of appearance of late spore properties in strain 520

Initially strain 520 was isolated after mutagenesis of strain 168 with NTG and a procedure for selecting mutant spores that germinate slowly and are also lysozyme-sensitive (Jenkinson, 1981). Colonies formed by this strain on PGYE agar (see Methods) were more translucent than those of the wild-type strain and, unlike colonies of the wild-type, they did not turn red when overlaid with tetrazolium-containing agar (see Methods) and incubated for $6-8 \mathrm{~h}$ at $37^{\circ} \mathrm{C}$. Furthermore, after sporulation in resuspension medium, about $20 \%$ of the spores at $t_{20}$ were sensitive to lysozyme. The remainder were as resistant to lysozyme as were wild-type spores and survived more than $3 \mathrm{~h}$ incubation with lysozyme $\left(250 \mu \mathrm{g} \mathrm{ml}-1,37^{\circ} \mathrm{C}\right)$. Since lysozyme resistance is the last of the resistance properties to develop (Jenkinson et al., 1980) this suggested that a proportion of the cells of the mutant might have failed to complete stage VI of sporulation.

To test this, the cells were induced to sporulate and, at various times after resuspension, the numbers of spores surviving treatment with toluene, with heat and with lysozyme were measured. In cultures of the wild-type, toluene resistance began to develop at about $t_{4}$, and spores resistant to heating $\left(80^{\circ} \mathrm{C}, 15 \mathrm{~min}\right)$ and resistant to lysozyme $\left(250 \mu \mathrm{g} \mathrm{ml} \mathrm{g}^{-1}, 37^{\circ} \mathrm{C}, 30 \mathrm{~min}\right)$ appeared at about $t_{5.5}$ and $t_{6}$, respectively (Fig. 1). The appearance of each of these resistance properties in strain 520 was delayed by about 40 to $60 \mathrm{~min}$ (Fig. 1). The spores, nevertheless, achieved full resistance to toluene and heat, but lysozyme resistance was particularly slow to develop, and even at $t_{10}$, when a plateau was reached, $30 \%$ of the spores remained sensitive to lysozyme (Fig. 1).

Amounts of extracellular serine protease, alkaline phosphatase, extracellular sporulation endonuclease, glucose dehydrogenase and dipicolinic acid produced by strain 520 were similar to those produced by strain 168 , and these marker events appeared at the same times during sporulation of the mutant as they did in the wild-type (results not shown).

\section{Germination properties}

To test the germination characteristics of the spores produced by strain 520, cleaned $t_{20}$ spores were suspended in either L-alanine $(10 \mathrm{mM})$, Penassay broth, or glucose/fructose/asparagine/ $\mathrm{KCl}$ (10 $\mathrm{mm}$ each) and the numbers of spores remaining ungerminated (tested by their ability to survive treatment with toluene) were measured at intervals. Over $80 \%$ of the spores of the wildtype germinated in L-alanine in 90 min (Fig. 2), whereas only about $30 \%$ of the mutant spores had germinated, even after $5 \mathrm{~h}$ (Fig. 2). A comparable delay in germination of mutant spores was observed in Penassay broth and in glucose/fructose/asparagine $/ \mathrm{KCl}$ (results not shown). Similar germination deficiencies were observed in spores of strain 520.3, a derivative of strain CU267 into which the spo-520 mutation had been transferred by DNA-mediated transformation (see Table 1).

\section{Spore coat proteins}

To see if the germination defects of the mutant were associated with an altered spore coat (see Introduction), spores were harvested from cultures of the wild-type and mutant strains at $t_{10}$ and their coat protein profiles were compared after SDS-PAGE. The gel patterns were similar, although the relative amount of one of the major components (the $36 \mathrm{~K}$ polypeptide) was reduced in the mutant (Fig. 3). 


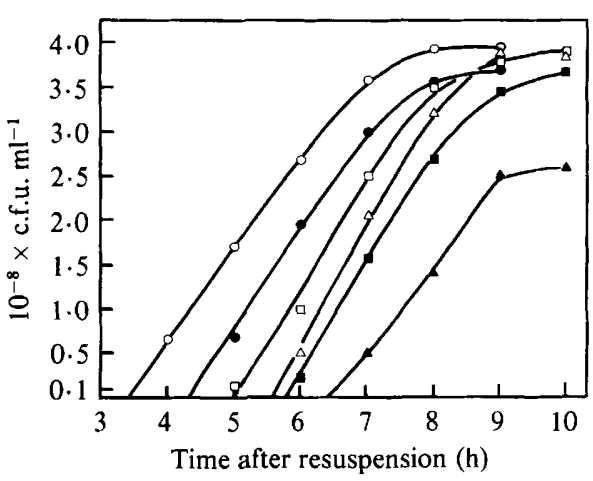

Fig. 1

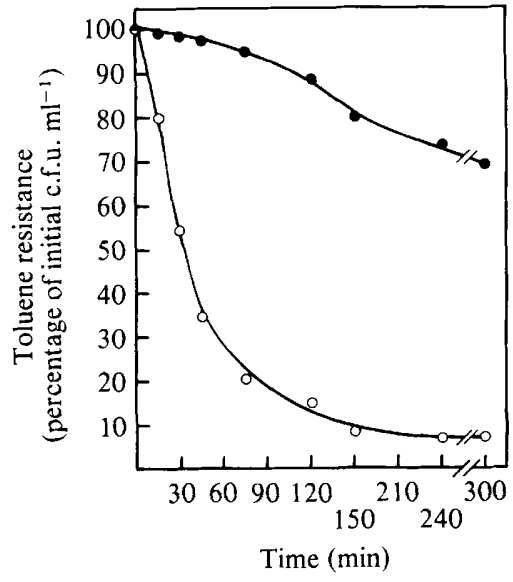

Fig. 2

Fig. 1. Development of resistance to toluene $(O, \boldsymbol{O})$, heating $(\square, \square)$ and lysozyme $(\triangle, \boldsymbol{\Delta})$ during sporulation of the wild-type (open symbols) and strain 520 (filled symbols).

Fig. 2. Germination of spores of the wild-type $(\mathrm{O})$ and strain $520(O)$ in $10 \mathrm{~mm}$-L-alanine. Cleaned spores were suspended to a density of $5 \times 10^{7}$ spores $\mathrm{ml}^{-1}$ in Tris/HCl buffer $(10 \mathrm{mM}, \mathrm{pH} 8 \cdot 2)$ containing $L$-alanine $(10 \mathrm{mM})$ and germination was followed by measurement of the numbers of spores surviving treatment with toluene (see Methods).

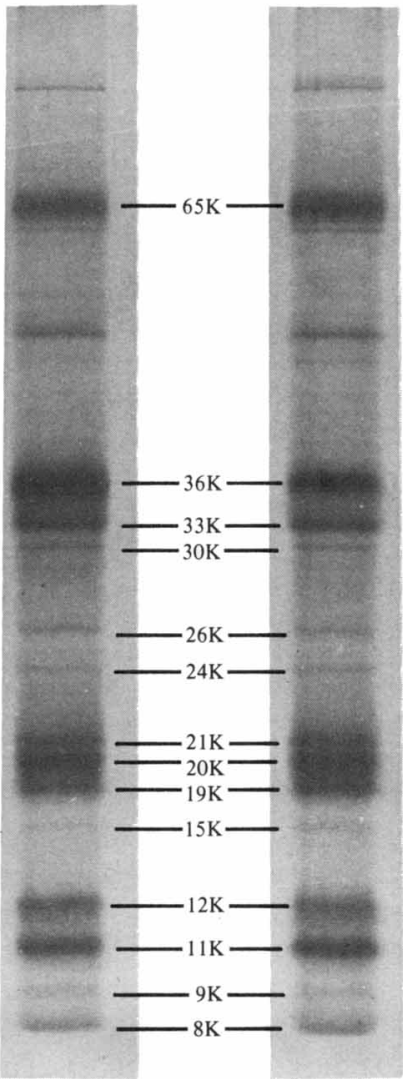

Fig. 3. SDS-PAGE profiles of proteins stained with Coomassie blue from the spore coat fractions of spores of strain 168 (lane A) and strain 520 (lane B). Polypeptide bands are labelled with their approximate molecular weights $(\mathrm{K}=\mathrm{kDal})$. 


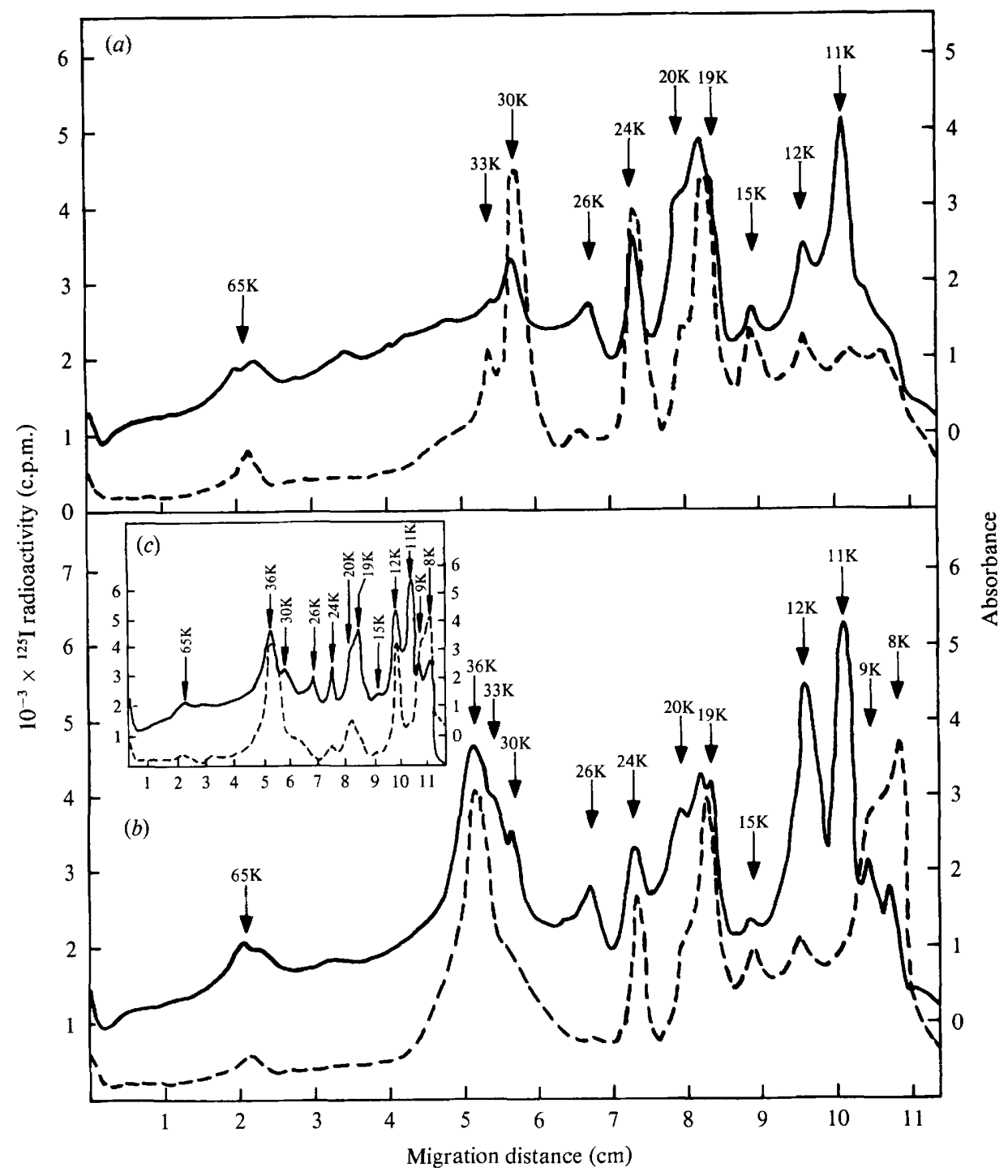

Fig. 4. Surface iodination of proteins on spores of (a) strain 520 at $t_{6 \cdot 8}$, (b) strain 520 at $t_{10}$, and (c) wildtype at $t_{10}$. Spores were isolated from sporangia and surface-labelled with ${ }^{125} \mathrm{I}$ as described in Methods. The spore coat proteins were fractionated by SDS-PAGE and the gels stained with Coomassie blue. They were scanned with a densitometer and then sliced into $1 \mathrm{~mm}$ sections which were counted for radioactivity in a gamma-counter. -, Densitometer scan (absorbance); ---, ${ }^{125}$ I radioactivity.

\section{Surface-protein iodination}

Four of the coat proteins $(36 \mathrm{~K}, 12 \mathrm{~K}, 9 \mathrm{~K}$ and $8 \mathrm{~K})$ have been shown to be prominent components on the surface of mature $\left(t_{9}\right)$ spores of the wild-type (Jenkinson et al., 1981). Several of the other proteins in the outer spore layers are not surface-exposed in mature spores and are presumed to be partially or completely overlaid. Although the coat proteins of the mutant spores were qualitatively the same as those of the wild-type, it was possible that their arrangement was different. Accordingly, spores of strain 520, allowed to develop to maturity $\left(t_{10}\right)$ were surfacelabelled with ${ }^{125} \mathrm{I}$ using lactoperoxidase (see Methods). The coat proteins were extracted, fractionated by SDS-PAGE, and the radioactivity associated with each band was determined.

The pattern of surface-labelling in the proteins of the coat of the mutant spores was different from the pattern in the wild-type. Thus, in the latter, most of the radioactivity was found in four 


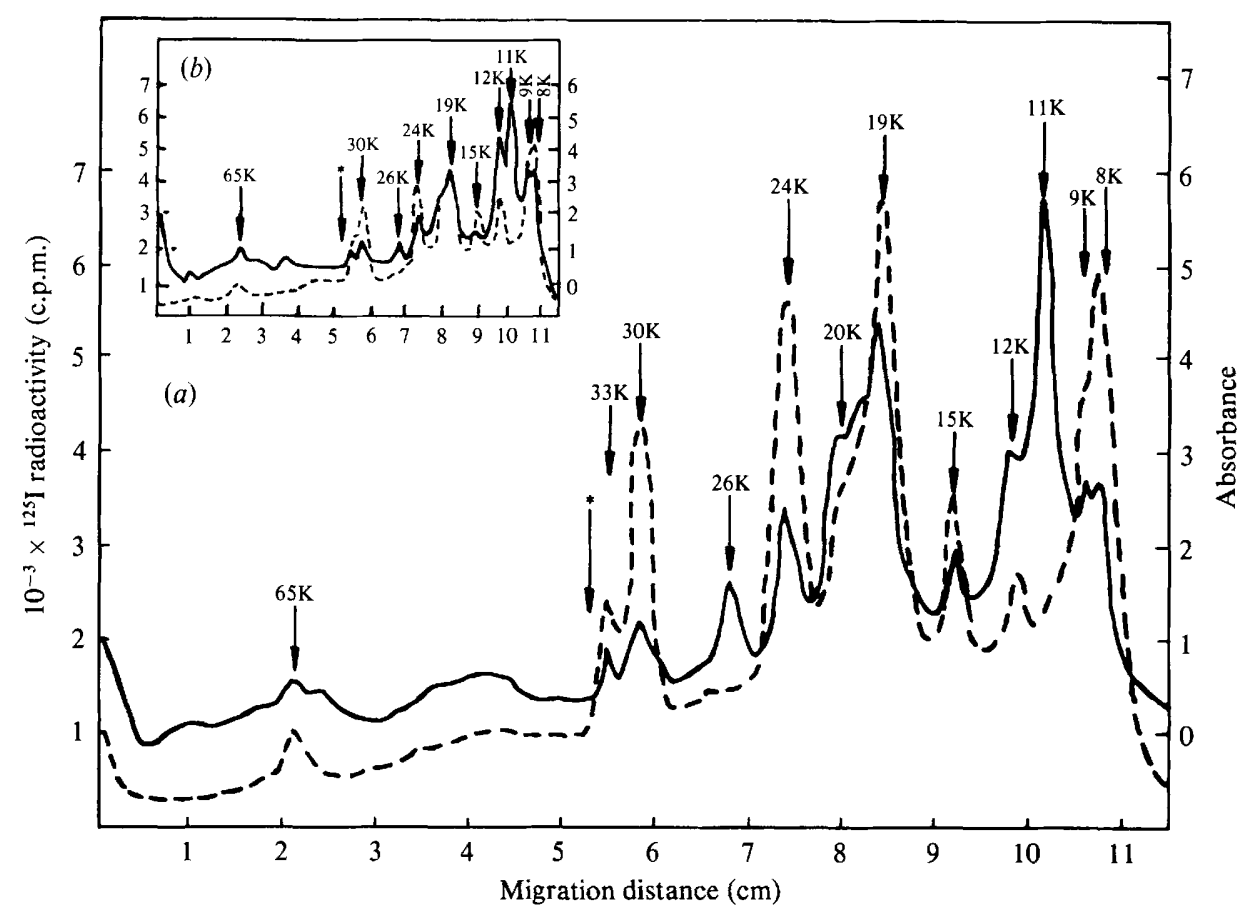

Fig. 5. Surface iodination of proteins of mature spores $\left(t_{10}\right)$ from $(a)$ double mutant strain 524 , and $(b)$ strain 513. Spores were isolated from sporangia, labelled, and the coat proteins separated by SDSPAGE and scanned as described in the legend to Fig. 4. - Densitometer scan (absorbance); ---, ${ }^{25} \mathbf{I}$ radioactivity. The asterisk marks the position of the missing $36 \mathrm{~K}$ polypeptide.

proteins $(36 \mathrm{~K}, 12 \mathrm{~K}, 9 \mathrm{~K}$ and $8 \mathrm{~K}$ ), with some labelling in the $20 \mathrm{~K}, 19 \mathrm{~K}$ and $15 \mathrm{~K}$ bands (Fig. $4 c$ ). In the mutant, the $36 \mathrm{~K}, 9 \mathrm{~K}$ and $8 \mathrm{~K}$ bands were also surface-labelled but the $12 \mathrm{~K}$ band was virtually unlabelled (Fig. $4 b$ ); in addition the $30 \mathrm{~K}$ and $24 \mathrm{~K}$ polypeptides not normally exposed on wild-type spores were labelled (Fig. $4 b$ ). The same abnormal pattern of labelling was observed when spores of the isogenic strain 520.3 were surface-iodinated at $t_{10}$.

Further experiments done by isolating spores of strain 520 at earlier times $\left(t_{5.5}\right.$ and $\left.t_{6.8}\right)$ and surface-labelling them, showed that the $12 \mathrm{~K}$ polypeptide begins to be deposited in the coat of the mutant spores at the same time (after $t_{6}$ ) as it does in the wild-type. At $t_{6.8}$ the $12 \mathrm{~K}$ protein was surface-labelled (Fig. $4 a$ ) and the labelling pattern in the proteins was virtually identical to that in the wild-type at $t_{6.5}$ (Jenkinson et al., 1981).

\section{Construction of a double mutant}

The results above appear to show that between $t_{6.8}$ and $t_{10}$ in the mutant, the $12 \mathrm{~K}$ protein was assembled differently into the spore outer layers. Since the $36 \mathrm{~K}$ polypeptide of the coat in the wild-type is made late in sporulation and is deposited together with the $12 \mathrm{~K}$ protein (Jenkinson et al., 1981), it was possible that in the mutant strain 520 the $36 \mathrm{~K}$ protein was deposited abnormally so that it covered the $12 \mathrm{~K}$ polypeptide. To test this possibility, the mutation spo-513 which causes loss of the $36 \mathrm{~K}$ polypeptide (Jenkinson, 1981) was introduced into strain 520 by transformation (see Table 1).

To show genetically that this double mutant, strain 524 , contained both mutations, DNA was prepared from it and used at saturating concentration to transform strain MB 79 metC 3 phe A12 to $\mathrm{Met}^{+}$. Under these conditions approximately $5 \%$ congression of unlinked genes should occur, and in fact out of 660 transformants 31 had the spo-513 phenotype and 36 had the spo-520 phenotype, confirming that strain 524 carried both mutations.

The spores of the double mutant (which lacked the $36 \mathrm{~K}$ polypeptide, Fig. $5 a$ ) were then surface-iodinated as described above, and the distribution of ${ }^{125} I$ in the coat proteins compared 
Table 2. Comparison of germination rate and lysozyme sensitivity of spores from strains 513 , 520, 524 and 168 (wild-type)

Spores were germinated in $10 \mathrm{mM}$-L-alanine, or treated with lysozyme $\left(250 \mu \mathrm{g} \mathrm{ml}^{-1}, 37^{\circ} \mathrm{C}, 30 \mathrm{~min}\right)$ as described in Methods.

$\begin{array}{ccc}\text { Germination } & \begin{array}{c}\text { (percentage loss in } A_{550} \\ \text { after } 3 \mathrm{~h} \text { ) }\end{array} & \begin{array}{c}\text { Lysozyme sensitivity } \\ \text { (percentage loss in viability)* }\end{array} \\ 513 & 30 \dagger & 80 \dagger \\ 520 & 25 & 28 \\ 524 & 8 & 91 \\ 168 & 55 & 3\end{array}$

* The initial viable count was $5 \times 10^{7}$ spores $\mathrm{ml}^{-1}$.

$\dagger$ Data from Jenkinson (1981).

with that in the coat proteins of each of the parent strains (Figs $4 b$ and $5 b$ ). In the double mutant the $30 \mathrm{~K}, 24 \mathrm{~K}, 19 \mathrm{~K}$ and $15 \mathrm{~K}$ proteins were more exposed than in either parent, these being the polypeptides which have been shown previously to be covered by the $36 \mathrm{~K}$ protein (Jenkinson, 1981). More significantly, however, the relative amount of the $12 \mathrm{~K}$ polypeptide in the coat of the double mutant was only about $20 \%$ of that found in the coat extracts of either parent. Also, in the double mutant this protein was surface-iodinated (Fig. $5 a$ ). From these results it was not possible to conclude that in strain 520 the $36 \mathrm{~K}$ protein covered the $12 \mathrm{~K}$ protein.

The spores of the double mutant were slower to germinate than the spores of either parent (Table 2) and they were more sensitive to lysozyme than spores of strain 513 (Table 2).

\section{Mapping of spo-520}

Mapping of the mutation in strain 520 was first carried out by phage PBS1-mediated transduction. The mutation (spo-520) was $94 \%$ (183/193) cotransducible with leuA8 (strain MB21 as recipient), 86\% (260/300) cotransducible with $i l v B 2$ (strain CU267 as recipient) and $34 \%(17 / 50)$ cotransducible with phe $A 12$ (MB68 as recipient). It was not cotransducible with cysA14, his Al, metC3 or $l y s-1$.

Further mapping by transformation showed that $s p o-520$ was $38 \%$ cotransformable with leuA8 (see Table 3). Since the cotransduction and cotransformation frequencies observed for spo-520 were similar to those for gerE36 (Moir, 1981), and this latter mutation, which also affects spore coat deposition, maps between citF2 and leu-2 (Moir, 1981), it was worth checking whether spo-520 and gerE36 were closely linked. To do this, strain 4823 leu- 2 citF 2 was transformed with DNA from strain 520 and $\mathrm{Cit}^{+} \mathrm{Leu}^{+}$recombinants were selected and scored for cotransformation of spo-520. In this cross, $54 \%$ of the recombinants carried the sporulation and germination defect (Table 3) while in a corresponding cross of strain 4823 with 4673 gerE36, $96 \%$ of the $\mathrm{Cit}^{+} \mathrm{Leu}^{+}$recombinants were germination-defective (Table 3), suggesting the order citF2-gerE36-leu-2. Since in other crosses, spo-520 was more closely linked to leuA8 (38\%) than to $\operatorname{cit} F 78(8 \%)$ (results not shown), and since it seems not to map between the two outside markers, the results suggested that the relative gene order is citF78-citF2-leu-2-spo-520.

A three factor cross was then carried out in which strain CU267 trpC2 ilvB2 leuB16 was transformed with DNA from strain $520 \operatorname{trpC2} s p o-520$. When $\mathrm{Leu}^{+}$recombinants were selected and scored for transformation of ilv and spo, $47 \%$ of the $\mathrm{Leu}^{+}$transformants were $\mathrm{Spo}^{-}$and no rare class of recombinants was generated. This suggests that leuB lies between the other two markers. This was checked by selecting for Ilv ${ }^{+}$recombinants. Of these only $3 / 188$ were $\mathrm{Leu}^{-} \mathrm{Spo}^{-}$, thus confirming that the gene order was ilvB2-leuB16-spo-520 (Table 3). DNA from strain 4673 gerE36 was also used to transform strain CU267, and in this case the rare class of recombinants was generated when $\mathrm{Leu}^{+}$transformants were selected (Table 3) confirming the order gerE36ilvB2-leuB16 determined by Moir (1981) using phage SPP1 transduction. Thus gerE36 and spo520 are separated by the leu genes, and both are separate from spo-513, a recently described mutation affecting spore coat production (Jenkinson, 1981) which is unlinked to leuA 8 by transformation (unpublished results). 

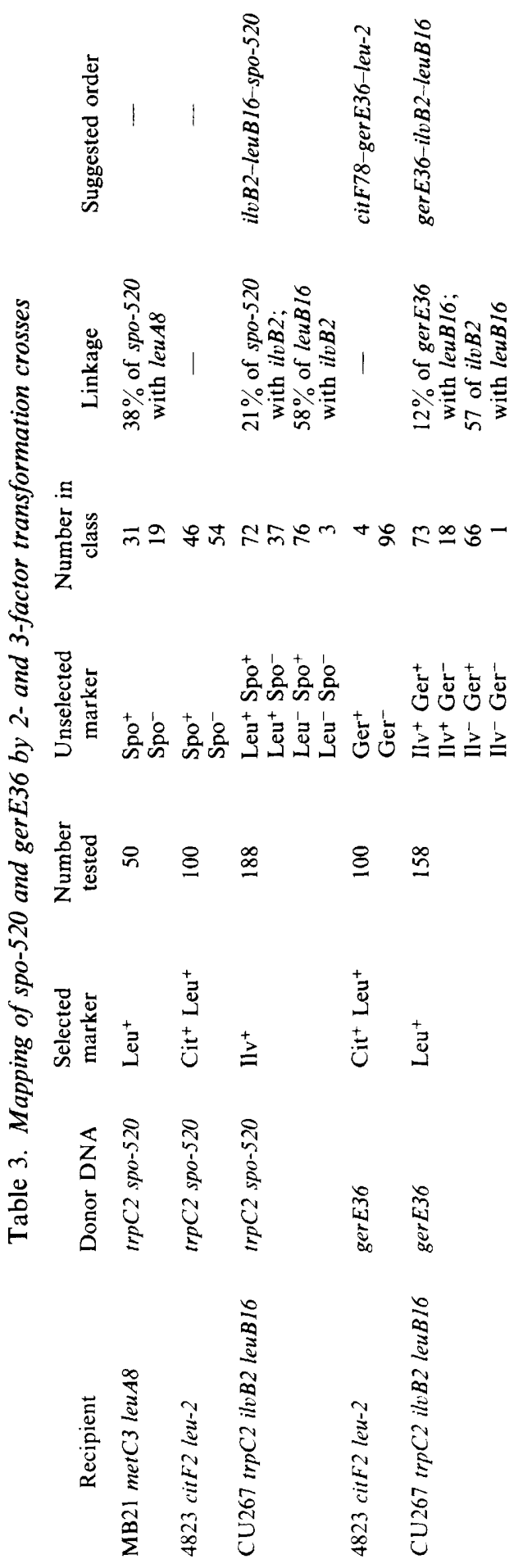
As a final check on these results, the recombination index (Lacks \& Hotchkiss, 1960) between gerE36 and spo-520 was determined as described by Coote (1972). From two separate experiments the R.I. was calculated to be 0.98 (data not shown) thus confirming that the mutations are not linked by transformation.

\section{Isolation of further sporulation mutants with mutations in the same region}

To try to isolate further germination mutants with mutations close to spo-520, a localized mutagenesis was carried out using mutagenized DNA extracted from the wild-type strain. A suitable way of doing this would have been to use the closely-linked mutation leuB 16, select $\mathrm{Leu}^{+}$ transformants, and to look amongst these for stage VI mutants. However it is difficult to distinguish these mutants from a $\mathrm{Spo}^{+}$background, so to circumvent this problem an uncharacterized sporulation mutant blocked at stage IV, recently isolated in this laboratory, and whose mutation was about $20 \%$ linked by transformation to leuB 16 , was used as recipient. After the transformation, Schaeffer's sporulation medium $(3 \mathrm{ml}$; Schaeffer et al., 1965) was added. The culture was allowed to sporulate for $16 \mathrm{~h}$ at $37^{\circ} \mathrm{C}$ and then it was heated $\left(80^{\circ} \mathrm{C}, 15 \mathrm{~min}\right)$ to kill cells. This eliminates any $\mathrm{Spo}^{-}$recipients or transformants, and selects for $\mathrm{Spo}^{+}$transformants. The suspension was centrifuged, the pellet suspended in Penassay broth $(5 \mathrm{ml})$ and the spores were incubated for $2 \mathrm{~h}$ at $37^{\circ} \mathrm{C}$ with shaking to germinate them. The culture was then heated again to kill germinated spores, and thus to select for slow germinators, and portions $(0.2 \mathrm{ml})$ were plated on to PGYE agar. After overnight incubation at $37^{\circ} \mathrm{C}$, colonies appeared at a frequency of about 10 per plate and a number were picked and tested for defective germination on PGYE/tetrazolium agar (see Methods). Three strains were purified on the basis of preliminary mapping data which indicated that each strain carried a separate mutation.

\section{Phenotypic properties of strains 541,547 and 552}

The phenotypic properties of these three strains were identical to those of strain 520, i.e. they sporulated more slowly than the wild-type and the spores germinated more slowly. In Fig. 6 the germination rates of the spores from isogenic derivatives of each mutant strain (see Table 1) in $10 \mathrm{mM}$-L-alanine are compared with those of strain 520.3 and strain CU267 (Spo $^{+}$isogenic parent). The mutants had distinctly different germination rates and these always followed the order CU267>520.3>541.1>547.1>552.1. Surface iodination of $t_{10}$ spores of strains 541, 547 and 552 (and of the isogenic strains 541.1 etc.) showed the same pattern of abnormal labelling in the coat proteins as that in strain 520 , i.e. the $12 \mathrm{~K}$ protein was virtually un-iodinated, and the $24 \mathrm{~K}$ and $19 \mathrm{~K}$ polypeptides were heavily labelled.

\section{Solubility of coat protein of mutant spores}

Treatment of $B$. subtilis spores with $50 \mathrm{~mm}$-DTT in $8 \mathrm{M}$-urea at $\mathrm{pH} 3$, followed by $0 \cdot 1 \mathrm{M}$ $\mathrm{NaOH}$, renders them extremely sensitive to lysis by lysozyme (Gould et al., 1970). Since the coat proteins of the mutant strains described here were apparently misarranged it was possible that the coat proteins would be more readily solubilized with the above agents than those of the spores of a wild-type strain. Accordingly, $t_{20}$ spores of the isogenic derivatives of the four mutants and of strain CU267 were treated with the above agents as described in Methods, and their subsequent rates of lysis upon the addition of lysozyme were measured by the fall in absorbance at $550 \mathrm{~nm}$. The results in Fig. 7 show that the spores of strain CU267 (normal spores) lysed fairly rapidly in lysozyme after the treatment $(50 \%$ loss of absorbance in $10 \mathrm{~min})$. However, the spores of the mutant strains all lysed far more rapidly than this and the fastest of these (strain 547) lost 50\% absorbance in $2 \mathrm{~min}$ (Fig. 7). Thus as a result of the misarrangement of the coat proteins the extracted spores were more susceptible to lysozyme treatment (i.e. the proteins were more readily solubilized by reducing agent-alkali).

\section{Genetic mapping}

The mutations spo-541, spo-547 and spo-552 were respectively $41 \%(170 / 416), 42 \%(175 / 416)$ and $50 \%(208 / 416)$ cotransformable with leuB 16 . The recombination index between each of these three mutations and spo-520 was estimated to be $<0.05$ (Table 4) but their relative order 


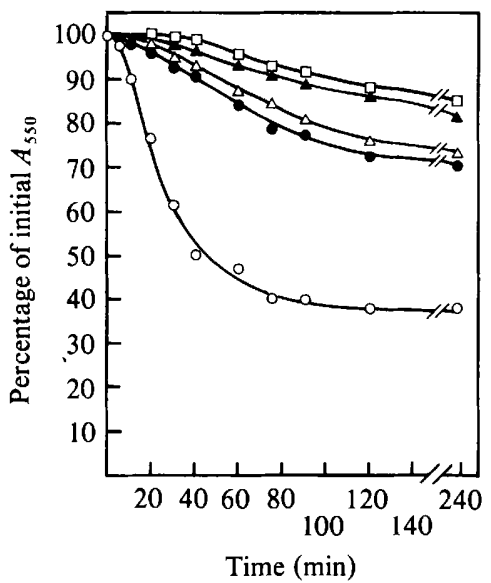

Fig. 6

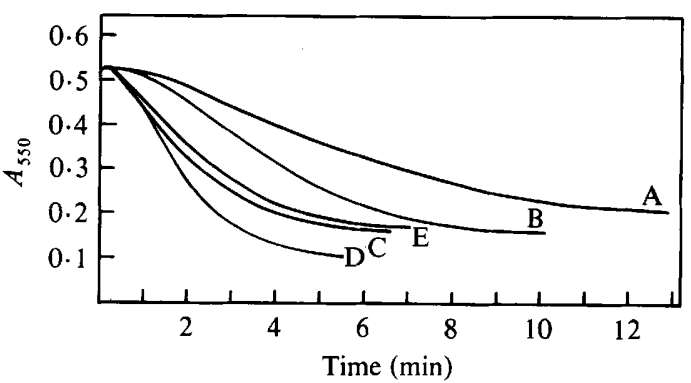

Fig. 7

Fig. 6. Germination of spores of strains CU267 (normal spores) $(O), 520.3(\bigcirc), 541.1(\triangle), 547.1(\Delta)$ and $552.1(\square)$ in $10 \mathrm{mM}$-L-alanine. Cleaned spores were suspended at an $A_{550}$ of 0.35 in Tris/ $\mathrm{HCl}$ buffer (10 mM, pH 8.2) containing L-alanine ( $10 \mathrm{mM}$ ) and germination followed by the fall in $A_{550}$.

Fig. 7. Lysis of spores of strains CU267 (A), 520.3 (B), 541.1 (C), 547.1 (D) and 552.1 (E) in lysozyme after treatment with dithiothreitol/urea and $\mathrm{NaOH}$ as described in Methods. Treated spores in $1 \mathrm{ml}$ $\mathrm{NaH}_{2} \mathrm{PO}_{4} / \mathrm{NaOH}$ buffer $(100 \mathrm{mM}, \mathrm{pH} 7)$ were warmed to $37^{\circ} \mathrm{C}$ in a cuvette within a heated block in a Pye Unicam SP800 spectrophotometer. Lysozyme $\left(0.01 \mathrm{ml}\right.$ of a $20 \mathrm{mg} \mathrm{ml}^{-1}$ solution in $\mathrm{NaH}_{2} \mathrm{PO}_{4} /$ $\mathrm{NaOH}$ buffer) was added and the fall in $A_{550}$ was automatically recorded.

Table 4. Recombination index between spo-541, spo-547, spo-552 and spo-520

Strain 520.1 metC3 was used as recipient in a transformation cross with DNA at saturating concentration $\left(5 \mu \mathrm{g} \mathrm{ml}^{-1}\right)$ from each of the other strains and from the wild-type $168 \mathrm{trpC} 2$ (control). $\mathrm{Met}^{+}$ transformants were selected and colonies first purified on lactate/glutamate minimal agar and then picked on to PGYE agar to score for $\mathrm{Spo}^{+}\left(\mathrm{Ger}^{+}\right)$.

$\begin{array}{ccccc} & \text { Donor DNA } & \mathrm{Spo}^{+} / \mathrm{Met}^{+} & \begin{array}{c}\mathrm{Spo}^{+} \\ \mathbf{( \% )}\end{array} & \begin{array}{c}\text { Recombination } \\ \text { index }\end{array} \\ \text { Experiment 1 } & 541 & 0 / 516 & 0 & <0.042 \\ & 552 & 0 / 516 & 0 & <0.042 \\ \text { Experiment 2 } & 168 & 24 / 516 & 4.651 & - \\ & 541 & 1 / 936 & 0 \cdot 107 & 0.018 \\ & 547 & 1 / 936 & 0 \cdot 107 & 0.018 \\ & 552 & 2 / 936 & 0 \cdot 214 & 0.036 \\ & 168 & 12 / 204 & 5.882 & -\end{array}$

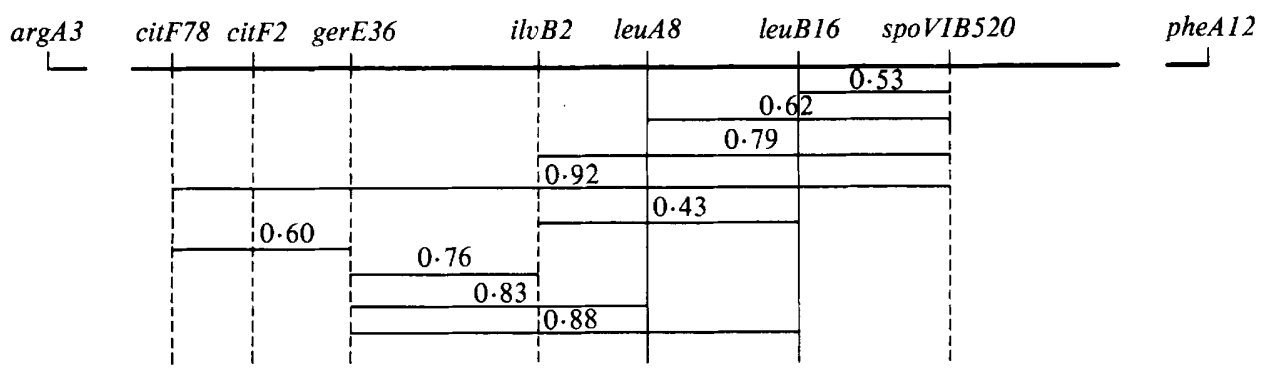

Fig. 8. Map of the leu region showing genetic distances of gerE36 and spoVIB520 mutations affecting spore coat deposition. Distances are in transformation units, $(100-\%$ cotransformation $) \div 100$. The transformation distance between $i l v B 2$ and leuB16 is similar to that determined by Ward \& Zahler (1973). 
was not determined from three-point crosses because of the difficulty in scoring large numbers of transformants. These four mutations together define a new sporulation locus, spoVIB, and a map of the region is shown in Fig. 8.

\section{DISCUSSION}

In general, spore coat mutants of Bacillus cereus which have been described have germination defects (Aronson \& Fitz-James, 1976; Stelma et al., 1978, 1980), and the two spore-coat mutants of B. subtilis that have been characterized also have germination defects (Moir, 1981 ; Jenkinson, 1981). If the germination and resistance properties are indeed dependent on the proper assembly of the coat then aberrations in assembly should be reflected by aberrations in these properties. The coat of the mutant strain 520 exhibits a number of abnormalities. First, the $12 \mathrm{~K}$ protein is largely overlaid in mature spores whereas in the wild-type it is prominent on the surface. Second, the assembly of the coat is delayed in relation to that in the wild-type. Third, the misarrangement of the proteins in the coats of the mutants causes the mutant spores to be unduly sensitive to lysozyme after extraction with reducing agent-alkali (Fig. 7). Finally, although the base layer of the coat (containing $26 \mathrm{~K}, 33 \mathrm{~K}, 65 \mathrm{~K}, 30 \mathrm{~K}, 15 \mathrm{~K}$ and $24 \mathrm{~K}$ proteins) in the mutant strain 520 is laid down in the normal way, a number of the proteins (e.g. $24 \mathrm{~K}, 19 \mathrm{~K}$ and $15 \mathrm{~K}$ ) show an abnormally high degree of surface labelling. The significance of the latter is uncertain and so is the fact that about $30 \%$ of the mutant spores at $t_{10}$ are lysozyme-sensitive. Both of these findings may be consequential effects arising from the delayed assembly of the coat. Thus, the mother cells of a sporulating culture begin to lyse after about $t_{9}$, and in those cells in which lysis takes place before the deposition of the $36 \mathrm{~K}$ polypeptide the spores concerned will be lysozymesensitive. In addition, those proteins in them that would normally have been overlaid by deposition of the $36 \mathrm{~K}$ protein will be more accessible to the surface-labelling agents and will exhibit an unusually high degree of iodination.

One explanation for the fact that the $12 \mathrm{~K}$ polypeptide in the mutant spores is not iodinated significantly would be to assume that it had been covered by the $36 \mathrm{~K}$ protein. To test this, a second mutation spo-513, which prevents the deposition of the $36 \mathrm{~K}$ polypeptide (Jenkinson, 1981) was introduced into strain 520. However, the amount of $12 \mathrm{~K}$ protein in the coat of the double mutant was considerably reduced, so the experiment provided no information about the relative arrangement of the $12 \mathrm{~K}$ and $36 \mathrm{~K}$ proteins in the mutant strain 520 . The result does suggest though, that in this mutant, but not in the wild-type, the deposition of the $12 \mathrm{~K}$ polypeptide is in some way dependent on the formation or deposition of the $36 \mathrm{~K}$ component.

Recently it has been suggested (Stewart \& Ellar, 1982) that some, perhaps the majority, of the proteins described as coat proteins in B. subtilis spores (Goldman \& Tipper, 1978; Jenkinson et al., 1981) are in fact components of the spore outer membrane. This supposition seems to ignore the fact that when iodination is carried out on mature spores, i.e. when labelling of membrane components is hardly likely, seven polypeptides are labelled in wild-type spores $(36 \mathrm{~K}, 12 \mathrm{~K}, 9 \mathrm{~K}$ and $8 \mathrm{~K}$ heavily, and $20 \mathrm{~K}, 19 \mathrm{~K}$ and $15 \mathrm{~K}$ partially). To these should be added the proteins labelled in strain $513(30 \mathrm{~K}$ and $24 \mathrm{~K}$ ) giving a total of at least nine proteins out of the 14 initially identified (Jenkinson et al., 1981). It is thus apparent that most of the proteins described are components of the coat and not of the membrane. This underlines the greater complexity of the B. subtilis spore coat compared with that of Bacillus megaterium.

The most likely explanation for the phenotypic properties of strain 520 is that one of the proteins of the coat is altered in primary sequence. However, despite attempts to show this by peptide analysis, there appeared to be no obvious differences between the $36 \mathrm{~K}, 24 \mathrm{~K}, 20 \mathrm{~K}, 19 \mathrm{~K}$ or $12 \mathrm{~K}$ proteins of mutant and wild-type. It is possible that one of the other coat proteins is different in the mutant, or that the mutation affects the activity of some processing enzyme or regulatory molecule required for coat assembly.

Three loci have been identified as being involved in spore coat production in B. subtilis. Mutations in spoVIA and gerE affect in addition to coat deposition, the germination and

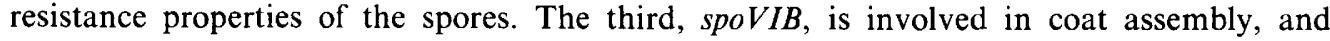
mutations within a small region of this locus (Fig. 8) give rise to slow development of resistance 
properties during sporulation, and to spores that are slow to germinate. The effects of mutation in spoVIA, spoVIB and gerE show that there is no fundamental distinction between spo and ger loci. Close examination of other germination mutants with mutations in other ger loci (Moir $e t$ al., 1979) might be expected to reveal differences in coat assembly.

I thank J. Mandelstam for many helpful discussions and for guidance, and Mary Blower for excellent technical assistance. This work was supported by the Science and Engineering Research Council.

\section{REFERENCES}

AKRIGG, A. (1978). Purification and properties of a manganese-stimulated deoxyribonuclease produced during sporulation of Bacillus subtilis. Biochemical Journal 172, 69-76.

Anagnostopoulos, C. \& Spizizen, J. (1961). Requirements for transformation in Bacillus subtilis. Journal of Bacteriology 81, 741-746.

ARonson, A. I. \& Fitz-JAMES, P. (1976). Structure and morphogenesis of the bacterial spore coat. Bacteriological Reviews 40, 360-402.

CoOTE, J. G. (1972). Sporulation in Bacillus subtilis. Genetic analysis of oligosporogenous mutants. Journal of General Microbiology 71, 17-27.

Dancer, B. N. \& Mandelstam, J. (1975). Production and possible function of serine protease during sporulation of Bacillus subtilis. Journal of Bacteriology 121, 406-410.

Dion, P. \& Mandelstam, J. (1980). Germination properties as marker events characterizing later stages of Bacillus subtilis spore formation. Journal of Bacteriology 141, 786-792.

GlenN, A. R. \& Mandelstam, J. (1971). Sporulation in Bacillus subtilis 168 . Comparison of alkaline phosphatase from sporulating and vegetative cells. Biochemical Journal 123, 129-138.

Goldman, R. C. \& TIPPER, D. J. (1978). Bacillus subtilis spore coats: complexity and purification of a unique polypeptide component. Journal of Bacteriology 135, 1091-1106.

Gould, G. W., Stubbs, J. M. \& King, W. L. (1970). Structure and composition of resistant layers in bacterial spore coats. Journal of General Microbiology 60, 347-355.

JANSSEN, F. W., LUND, A. J. \& ANDERSON, L. E. (1958). Colorimetric assay for dipicolinic acid in bacterial spores. Science $127,26-27$

JENKINSON, H. F. (1981). Germination and resistance defects in spores of a Bacillus subtilis mutant lacking a coat polypeptide. Journal of General Microbiology 127, 81-91.

Jenkinson, H. F., Kay, D. \& Mandelstam, J. (1980). Temporal dissociation of late events in Bacillus subtilis sporulation from expression of genes that determine them. Journal of Bacteriology 141, 793805.

Jenkinson, H. F., SAWYer, W. D. \& Mandelstam, J. (1981). Synthesis and order of assembly of spore coat proteins in Bacillus subtilis. Journal of General Microbiology 123, 1-16.

Karamata, D. \& Gross, J. D. (1970). Isolation and genetic analysis of temperature-sensitive mutants of B. subtilis defective in DNA synthesis. Molecular and General Genetics 108, 277-287.

LACKS, S. \& HotchKiss, R. D. (1960). A study of the genetic material determining an enzyme activity in Pneumococcus. Biochimica et biophysica acta 39, 508518.

LAEMMLI, U. K. \& FAVRE, M. (1973). Maturation of the head of bacteriophage T4. I. DNA packaging events. Journal of Molecular Biology 80, 575-599.

LAFFERTY, E. \& MoIR, A. (1977). Further studies on conditional germination mutants of Bacillus subtilis 168. In Spore Research 1976, pp. 87-105. Edited by A. N. Barker, J. Wolf, D. J. Ellar, G. J. Dring \& G. W. Gould. London: Academic Press.

MARMUR, J. (1961). A procedure for the isolation of deoxyribonucleic acid from micro-organisms. Journal of Molecular Biology 3, 208-218.

MolR, A. (1981). Germination properties of a spore coat-defective mutant of Bacillus subtilis. Journal of Bacteriology 146, 1106-1116.

MoIr, A., Lafferty, E. \& SMITH, D. A. (1979). Genetic analysis of spore germination mutants of Bacillus subtilis 168: the correlation of phenotype with map location. Journal of General Microbiology 111, 165-180.

Ohné, M., Rutberg, B. \& Hoch, J. A. (1973). Genetic and biochemical characterization of mutants of Bacillus subtilis defective in succinate dehydrogenase. Journal of Bacteriology 115, 738-745.

Piggot, P. J. (1973). Mapping of asporogenous mutations of Bacillus subtilis: a minimum estimate of the number of sporulation operons. Journal of Bacteriology 114, 1241-1253.

SADOFF, H. L. (1966). Glucose dehydrogenase-soluble. I. Bacillus cereus. Methods in Enzymology 9, 103 107.

Schaeffer, P., Ionesco, H., Ryter, A. \& Balassa, G. (1965). La sporulation de Bacillus subtilis: étude génétique et physiologique. Colloques internationaux du Centre national de la recherche scientifique 124, $553-563$.

Stelma, G. N., JR, Aronson, A. I. \& Fitz-J Ames, P. C. (1978). Properties of Bacillus cereus temperaturesensitive mutants altered in spore coat formation. Journal of Bacteriology 134, 1157-1170.

Stelma, G. N., JR, Aronson, A. I. \& Fitz-James, P. (1980). A Bacillus cereus mutant defective in spore coat deposition. Journal of General Microbiology 116 , 173-185.

Sterlini, J. M. \& Mandelstam, J. (1969). Commitment to sporulation in Bacillus subtilis and its relationship to development of actinomycin resistance. Biochemical Journal 113, 29-37.

Stewart, G. S. A. B. \& Ellar, D. J. (1982). Characterization, purification and synthesis of spore-coat protein in Bacillus megaterium KM. Biochemical Journal 202, 231-241. 
WARD, J. B., JR \& Zahler, S. A. (1973). Genetic studies of leucine biosynthesis in Bacillus subtilis. Journal of Bacteriology 116, 719-726.

Young, F. E. \& SPIZIzen, J. (1961). Physiological and genetic factors affecting transformation of Bacillus subtilis. Journal of Bacteriology 81, 823-829.
YudKin, M. D. \& TuRLey, L. (1980). Suppression of asporogeny in Bacillus subtilis: allele-specific suppression of a mutation in the spoIIA locus. Journal of General Microbiology 121, 69-78. 